\title{
ЭФФЕКТИВНОСТЬ ВЛИЯНИЯ ПОДКОРМКИ «АКВАРИН 5» НА УРОЖАЙНОСТЬ ЗЕРНА ЯРОВОЙ ПШЕНИЦЫ И ЕГО КАЧЕСТВО
}

\author{
Х.А. Пискунова (фото) \\ к.С.-х.Н., ведущий научный сотрудник отдела инновационных \\ разработок в растениеводстве \\ А.В. Федорова \\ старший научный сотрудник отдела инновационных \\ разработок в растениеводстве \\ ФГБНУ «Костромской научно-исследовательский институт \\ сельского хозяйства», с. Минское
}

Яровая пшеница - одна из самых распространённых культур на земном шаре и является основной зерновой культурой. Поэтому встаёт вопрос не только об увеличении её урожайности, но и об улучшении качества зерна. Создание новых высокопродуктивных сортов

Водорастворимое

удобрение, яровая

пшеница, урожнайнсть, качество зерна, сорта

Water-soluble fertilizer, spring wheat, yield, grain quality, varieties яровой пшеницы (Ладья, Каменка, Сударыня), полученных в результате сотрудничества между РУП «РПЦ НАН Беларуси по земледелию» и ФГБНУ «Владимирский НИИСХ», диктует необходимость совершенствования технологий возделывания этой культуры и изучения их реакции на внесение удобрений, в том числе и растворимых [1]. Растения нуждаются в макро- и микроэлементах на протяжении всей вегетации, но более всего в период кущения - начала выхода в трубку и формирования зерна. Поэтому в последнее время в практике сельскохозяйственного производства используются щадящие режимы регулирования минерального питания растений (некорневая подкормка водным раствором минеральных удобрений, содержащих основные макро- и микроэлементы в доступной и усвояемой форме). Действие водорастворимых удобрений базируется на быстром включении в метаболизм основных элементов питания и их влиянии на обменные процессы. В результате этого увеличивается использование элементов питания из почвы, повышается устойчивость растений к пониженным температурам, недостатку или избытку влаги. Но некорневая подкормка не может заменить основное внесение удобрений и должна выступать в качестве дополнительного способа питания.

«Акварин 5»- комплексное полностью растворимое минеральное удобрение. Оно усиливает поступление элементов питания в растения через корневую систему. Удобрение содержит полный набор микроэлементов в форме хелатов (\%): Fe-0,054, Zn-0,014, Cu-0,01, Mn0,042, Мо-0,004, B-0,02, при этом не содержит хлора и других вредных для растений соединений. Обработка «Акварин 5» может проводиться баковыми смесями со средствами защиты растений, выступая в роли антистрессанта [2, 3].

Цель исследований состояла в том, чтобы оценить влияние водорастворимого удобрения на урожайность и качество зерна яровой пшеницы. 
Результаты исследования показали, что применение полного комплексного удобрения «Акварин 5» является эффективным приёмом для некорневых подкормок зерновых культур $[4,5]$.

\section{Методика исследований}

В 2018 году опытный участок располагался в севообороте ОАО «Племзавод «Караваево». Кислотность почвы была слабокислой, по степе- ни гидролитической кислотности близка к нейтральной. Содержание гумуса низкое, фосфора повышенное, обменного калия - низкое. Почва относится к среднему классу.

Схема проведения опыта представлена в таблице 1.

В опыте применялась агротехника, общепринятая для Костромской области. Опыт заложен в трёх повторениях. Площадь делянки составила

Таблица 1 - Схема опыта

\begin{tabular}{|l|c|}
\hline \multicolumn{1}{|c|}{ Вариант опыта } & Характеристика \\
\hline Контроль & Без удобрений \\
\hline Вариант 1 & «Акварин 5» в дозе 1,5 кг/га в фазу выхода в трубку \\
\hline Вариант 2 & «Акварин 5» в дозе 3,0 кг/га в фазу выхода в трубку \\
\hline Вариант 3 & $\mathrm{N}_{26} \mathrm{P}_{38} \mathrm{~K}_{38}$ под культивацию и «Акварин 5» в дозе 1,5 кг/га в фазу выхода в трубку \\
\hline Вариант 4 & $\mathrm{N}_{26} \mathrm{P}_{38} \mathrm{~K}_{38}$ под культивацию и «Акварин 5» в дозе 3,0 кг/га в фазу выхода в трубку \\
\hline Вариант 5 & $\mathrm{N}_{26} \mathrm{P}_{38} \mathrm{~K}_{38}$ в чистом виде под культивацию \\
\hline
\end{tabular}

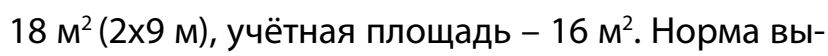
сева яровой пшеницы 5,0 млн всхожих зёрен на гектар.

Определение урожайности проводилось с пересчётом на 14\%-ную влажность и 100\%-ную чистоту. Качество сырой клейковины определяли на приборе ИДК-1. Статистическая обработка материалов осуществлялась с помощью компьютерной программы «AGROS-2.02».

Показатели качества зерна пшеницы определяли в соответствии с действующими методиками и ГОСТами. Фенологические наблюдения проводились по методике государственного сортоиспытания сельскохозяйственных культур. В опыте отмечались фазы развития растений, гу- стота стояния растений - в фазу полных всходов и перед уборкой с постоянных площадок.

Вегетационный период 2018 года отличался нестабильностью. В период вегетации яровой пшеницы с мая по вторую декаду июля ГТК в среднем составил 1,98 при среднемноголетнем значении за этот период 1,41. В период созревания зерна ГТК был 0,39-0,88 при норме 1,21-1,63.

\section{Результаты исследований}

Несмотря на то, что метеорологические условия не были благоприятны для роста и продуктивности яровой пшеницы, результаты исследований выявили положительное влияние «Акварин 5» на урожайность (табл. 2).

Таблица 2 - Влияние «Акварин 5» на урожайность яровой пшеницы, т/га

\begin{tabular}{|c|c|c|c|c|c|c|c|c|}
\hline \multirow{3}{*}{ Варианты } & \multicolumn{8}{|c|}{ Сорт яровой пшеницы } \\
\hline & \multicolumn{2}{|c|}{ Дарья (стандарт) } & \multicolumn{2}{|c|}{ Сударыня } & \multicolumn{2}{|c|}{ Ладья } & \multicolumn{2}{|c|}{ Каменка } \\
\hline & $\begin{array}{c}\text { урожай- } \\
\text { ность }\end{array}$ & $\begin{array}{c}+/- \text { к } \\
\text { контролю }\end{array}$ & $\begin{array}{c}\text { урожай- } \\
\text { ность }\end{array}$ & $\begin{array}{c}+/- \text { к } \\
\text { контролю }\end{array}$ & $\begin{array}{c}\text { урожай- } \\
\text { ность }\end{array}$ & $\begin{array}{c}+/- \text { к } \\
\text { контролю }\end{array}$ & $\begin{array}{c}\text { урожай- } \\
\text { ность }\end{array}$ & $\begin{array}{c}+/- \text { к } \\
\text { контролю }\end{array}$ \\
\hline Контроль & 1,38 & - & 1,32 & - & 1,39 & - & 1,41 & - \\
\hline Вариант 1 & 1,56 & 0,18 & 1,60 & 0,28 & 1,62 & 0,23 & 1,64 & 0,23 \\
\hline Вариант 2 & 1,75 & 0,37 & 1,79 & 0,47 & 1,83 & 0,44 & 1,81 & 0,40 \\
\hline Вариант 3 & 1,90 & 0,52 & 1,97 & 0,65 & 2,01 & 0,62 & 2,05 & 0,64 \\
\hline Вариант 4 & 2,11 & 0,73 & 2,21 & 0,89 & 2,24 & 0,85 & 2,29 & 0,88 \\
\hline Вариант 5 & 1,98 & 0,60 & 2,17 & 0,75 & 2,16 & 0,77 & 2,11 & 0,70 \\
\hline $\mathrm{HCP}_{05}$ т/га & 0,33 & $x$ & 0,26 & $x$ & 0,25 & $x$ & 0,26 & $x$ \\
\hline
\end{tabular}


Исследования показали, что при подкормке растений «Акварин 5» в чистом виде в дозе 1,5 кг/га урожайность зерна яровой пшеницы на всех вариантах опыта была практически одинаковой и составила от 1,56 до 1,64 т/га. Увеличение урожайности отмечено при подкормке в дозе 3,0 кг/га. Установлено также достоверное увеличение урожайности всех сортов яровой пшеницы на 0,52-0,89 т/га при внесении «Акварин 5» по фону минеральных удобрений. По минеральным удобрениям $\left(\mathrm{N}_{26} \mathrm{P}_{38} \mathrm{~K}_{38}\right)$ урожайность зерна культуры в опытных вариантах достоверно превысила контрольный вариант на 0,60-0,77 т/га.

Масса 1000 семян у сортов Сударыня, Ладья, Каменка при внесении «Акварин 5» в чистом виде в фазу выхода в трубку яровой пшеницы составила 30,7-31,4 г, а в контроле - 27,9-28,0 г. При подкормке «Акварин 5» в дозе 3,0 кг/га по фону минеральных удобрений масса 1000 зёрен увеличилась до 31,6-31,8 г, в то время как по минеральным удобрениям - до 29,5-31,2 г. У сорта Дарья (стандарт) масса 1000 зёрен меньше на 2,4-4,3 г, чем в среднем у изучаемых сортов.

Анализ структуры урожая показал, что применение «Акварин 5» способствовало увеличению длины стебля в среднем на 4,1\%, длины колоса - на 3,8\%, количества зёрен в колосе - на 5,2\%, массы зерна в колосе - на 6,2\%.

Погодные условия в период налива и созревания зерна оказали решающее влияние на показатель стекловидности зерна (табл. 3).

Подкормки «Акварин 5» в дозах 1,5 и 3,0 кг/га в чистом виде способствовали росту показателя стекловидности до 50,0-70,5\%. Внесение минеральных удобрений $\left(\mathrm{N}_{26} \mathrm{P}_{38} \mathrm{~K}_{38}\right)$ обеспечивало

Таблица 3 - Влияние «Акварин 5» на стекловидность зерна яровой пшеницы, \%

\begin{tabular}{|l|c|c|c|c|c|c|}
\hline \multirow{2}{*}{ Сорт } & \multicolumn{7}{c|}{ Вариант } & \multicolumn{2}{c|}{4} & 5 \\
\cline { 2 - 7 } & Контроль & 1 & 2 & 5 & 62,5 & 61,5 \\
\hline Дарья (стандарт) & 42,5 & 50,0 & 55,5 & 58,5 & 64,0 & 63,0 \\
\hline Сударыня & 50,0 & 56,5 & 57,0 & 60,0 & 78,0 & 79,0 \\
\hline Ладья & 53,5 & 65,0 & 70,5 & 71,5 & 69,0 & 69,0 \\
\hline Каменка & 51,0 & 60,5 & 62,0 & 67,0 & & \\
\hline
\end{tabular}

повышение показателя стекловидности зерна на 13,0-25,5\% в сравнении с контролем. Исследования показали, что по данному показателю сорт Ладья превосходил другие сорта.

Метеорологические условия во второй половине вегетации, а также подкормки удобрени- ем «Акварин 5» в фазу выхода растений в трубку оказали влияние на содержание белка и клейковины в зерне яровой пшеницы (табл. 4). Так, при внесении его в чистом виде в дозе 1,5 и 3,0 кг/га отмечено увеличение содержания белка в зерне на 0,46-1,89\% в сравнении с контролем, а при

Таблица 4 - Влияние водорастворимого удобрения на содержание белка и клейковины в зерне яровой пшеницы, \%

\begin{tabular}{|c|c|c|c|c|c|c|c|c|c|c|c|c|}
\hline \multirow[b]{3}{*}{ Сорт } & \multicolumn{12}{|c|}{ Вариант } \\
\hline & \multicolumn{2}{|c|}{ Контроль } & \multicolumn{2}{|c|}{1} & \multicolumn{2}{|c|}{2} & \multicolumn{2}{|c|}{3} & \multicolumn{2}{|c|}{4} & \multicolumn{2}{|c|}{5} \\
\hline & $\begin{array}{l}\text { ò } \\
\text { ص్ }\end{array}$ & 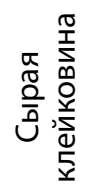 & 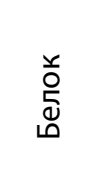 & 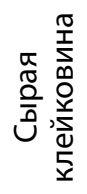 & $\begin{array}{l}\text { ò } \\
\text { ปे }\end{array}$ & 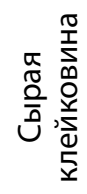 & $\begin{array}{l}\text { ๖े } \\
\text { ڤ్ }\end{array}$ & 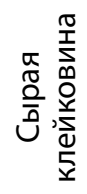 & $\begin{array}{l}\text { o } \\
\text { ڤ్ }\end{array}$ & 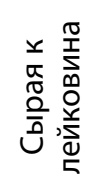 & $\begin{array}{l}\text { ठे } \\
\text { صू }\end{array}$ & 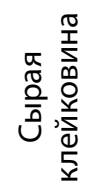 \\
\hline Дарья & 11,57 & 26,6 & 12,03 & 29,8 & 12,48 & 30,4 & 12,65 & 32,2 & 12,77 & 32,7 & 12,31 & 32,5 \\
\hline Сударыня & 11,51 & 26,8 & 12,12 & 30,4 & 13,40 & 32,0 & 13,54 & 32,9 & 13,31 & 33,4 & 12,03 & 33,0 \\
\hline Ладья & 11,60 & 27,1 & 12,14 & 30,1 & 13,05 & 33,4 & 13,62 & 33,8 & 14,59 & 34,0 & 13,00 & 33,6 \\
\hline Каменка & 10,94 & 26,6 & 11,58 & 29,9 & 12,48 & 29,2 & 12,34 & 31,3 & 13,11 & 32,0 & 12,15 & 31,5 \\
\hline
\end{tabular}


внесении в дозе 3 кг/га по минеральному фону количество белка возросло и достигло максимального значения у сорта Ладья - 14,59\%.

Наибольшее содержание клейковины отмечено в варианте с внесением «Акварин 5» в дозе 3,0 кг/га по минеральному фону на всех сортах яровой пшеницы $(32,7,33,4,34,0,32,0 \%$ соответственно). Анализ полученных данных показал, что клейковина зерна яровой пшеницы относилась ко второй группе качества и характеризовалась как удовлетворительная слабая.

\section{Выводы}

В условиях исследуемого года наиболее эффективным оказалось использование водорастворимого удобрения «Акварин 5» в дозе 3,0 кг/га по фону минеральных удобрений. Это обеспечило увеличение урожайности зерна яровой пшеницы на 0,73-0,89 т/га, формирование зерна большей массы (31,6-31,8 г), а также повышение содержания белка, клейковины и стекловидности на 1,202,99\%, 5,4-6,9\% и 14-24,5\% соответственно.

\section{Лumepamypa}

1. Гриб, С.И. Принципы и результаты экологической селекции яровой пшеницы для условий Беларуси и Нечерноземья России [Текст] / С.И. Гриб, Е.В. Игнатьева, А.Н. Зубикова и др. // Инновационные технологии возделывания сельскохозяйственных культур: сб. докладов. - Суздаль, 2013. - Т. 2. - С. 3-7.

2. Водорастворимые комплексные минеральные удобрения серии «Акварин» [Текст]: Проспект. - Буйский химический завод, 2003. - С. 1-2.

3. Оптимизация питания сельскохозяйственных культур на основе применения некорневых подкормок специальными удобрениями [Текст]: пособие для агрономов. - Буй, 2006. - С. 1-9.

4. Пискунова, Х.А. Применение «Акварин 5» на посевах яровой пшеницы [Текст] / Х.А. Пискунова, А.В. Федорова // Владимирский земледелец. - 2018. - № 3 (85). - С. 19-23.

5. Пискунова, Х.А. Влияние азотного удобрения на урожайность и качество продовольственного зерна яровой пшеницы [Текст] / Х.А. Пискунова, А.В. Федорова // Вестник АПК Верхневолжья. - 2018. - № 3 (43). - C. 14-18.

\section{References}

1. Grib, S.I. Principy i rezul'taty jekologicheskoj selekcii jarovoj pshenicy dlja uslovij Belarusi i Nechernozem'ja Rossii [Tekst] / S.I. Grib, E.V. Ignat'eva, A.N. Zubikova i dr. // Innovacionnye tehnologii vozdelyvanija sel'skohozjajstvennyh kul'tur: sb. dokladov. - Suzdal', 2013. - T. 2. - S. 3-7.

2. Vodorastvorimye kompleksnye mineral'nye udobrenija serii «Akvarin» [Tekst]: Prospekt. - Bujskij himicheskij zavod, 2003. - S. 1-2.

3. Optimizacija pitanija sel'skohozjajstvennyh kul'tur na osnove primenenija nekornevyh podkormok special'nymi udobrenijami [Tekst]: posobie dlja agronomov. - Buj, 2006. - S. 1-9.

4. Piskunova, Kh.A. Primenenie «Akvarin 5» na posevah jarovoj pshenicy [Tekst] / Kh.A. Piskunova, A.V. Fedorova // Vladimirskij zemledelec. - 2018. - № 3 (85). - S. 19-23.

5. Piskunova, Kh.A. Vlijanie azotnogo udobrenija na urozhajnost' i kachestvo prodovol'stvennogo zerna jarovoj pshenicy [Tekst] / Kh.A. Piskunova, A.V. Fedorova // Vestnik APK Verhnevolzh'ja. - 2018. - № 3 (43). S. 14-18. 